\title{
Analisis Kandungan Kimia Daun Dan Batang Sembukan (Paederia Foetida) Dengan Menggunakan 2 Pelarut Yang Berbeda Surahmaida $^{1 *)}$, Prasetyo Handrianto ${ }^{1}$ \\ ${ }^{1}$ Akademi Farmasi Surabaya \\ ${ }^{*}$ E-mail: fahida1619@gmail.com
}

\begin{abstract}
ABSTRAK
Tanaman sembukan (Paederia foetida) atau yang lebih kita kenal dengan daun kentut merupakan tanaman yang biasanya digunakan oleh masyarakat sebagai obat diare atau obat kembung. Kandungan senyawa metabolit sekunder tanaman sembukan perlu dikaji lebih lanjut untuk penemuan bahan obat baru. Tujuan dari penelitian adalah untuk menganalisis kandungan senyawa metabolit sekunder yang terdapat pada daun dan batang sembukan dengan metode maserasi yang direndam ke dalam pelarut etanol $96 \%$ dan metanol selama 5 hari. Ekstrak etanol dan ekstrak metanol pada masing-masing daun dan batang kemudian dianalisis dengan menggunakan reagen kimia untuk mengidentifikasi senyawa alkaloid, saponin, tanin dan flavonoid. Hasil skrining fitokimia menunjukkan bahwa pada ekstrak etanol dan metanol batang sembukan mengandung alkaloid, saponin, tanin dan flavonoid. Sedangkan pada ekstrak etanol dan metanol daun sembukan mengandung alkaloid, tanin dan flavonoid. Selanjutnya senyawa metabolit sekunder tersebut dianalisis aktivitas biologisnya.
\end{abstract}

Kata kunci: Analisis senyawa metabolit sekunder, ekstrak etanol dan metanol daun dan batang sembukan (Paederia foetida), maserasi

\section{ABSTRACT}

Paederia foetida or more familiar with fart leaves is a plant that is usually used by the community as a drug or bloated diarrhea. The content of the secondary metabolite compound of the Paederia foetida plant needs to be studied further for the discovery of new drug ingredients. The purpose of this research is to analyze the content of secondary metabolite compounds found on leaves and stems with a maseration method soaked in $96 \%$ ethanol solvent and methanol for 5 days. The ethanol extract and methanol extract on each leaf and stem were then analyzed using chemical reagents to identify the alkaloid compounds, saponins, tanins and flavonoids. The results of phytochemical screening showed that in the ethanol extract and methanol the stem of the Paederia foetida contained alkaloids, saponins, tanins and flavonoids. While on ethanol extract and methanol leaves Paederia foetida contains alkaloids, tanins and flavonoids. Furthermore, the secondary metabolite compounds are analyzed biological activity.

Keywords: Analysis of secondary metabolite compounds, ethanol extract and methanol leaves and stirring stem (Paederia foetida), maceration

\section{PENDAHULUAN}

Meskipun obat-obatan modern tersedia, tanaman obat mempertahankan citra mereka untuk alasan historis dan budaya. Tanaman obat berperan dalam menjaga kesehatan masyarakat [1]. Indonesia merupakan salah satu negara dimana masyarakatnya banyak memanfaatkan bahan alam dari tumbuhan untuk menangani masalah kesehatan.

Suku kopi-kopian (Rubiaceae) merupakan salah satu yang terbesar di kelas Magnoliopsida, dan menempati urutan keempat dalam keragaman spesies di antara Angiosperm [2]., yang memiliki 637 genus dan 13 ribu spesies [3,4]. Suku Rubiaceae menghasilkan banyak senyawa metabolit bioaktif dan memiliki potensi farmakologi yang besar [5].. Salah satu tanaman Rubiaceae yang banyak dimanfaatkan sebagai obat adalah tanaman sembukan (Paederia foetida).

Sembukan (Paederia foetida) berasal dari Asia Timur dan sekarang menjadi tanaman hias di seluruh dunia. Keterangan nama foetida menandakan bahwa tumbuhan tersebut berbau busuk. Umumnya, masyarakat menyebut sembukan dengan nama "daun kentut". Bau busuk dari sembukan ini keluar bila digosokkan di antara telapak tangan, dimakan, dan tercium saat sore hari [6]. Tanaman ini dimanfaatkan masyarakat sebagai bahan makanan (botok), lalapan, obat diare, mengatasi maag, detoksifikasi (penawar racun), meningkatkan produksi sel darah putih, obat cacing, pereda kejang dan lain-lain [6,7]. 
Hal ini dikarenakan adanya kandungan senyawa metabolit sekunder pada sembukan seperti flavonoid, terpenoid, paedorolone, $\beta$-sitosterol, friedelin, campesterol dan senyawa aktif lainnya [8].

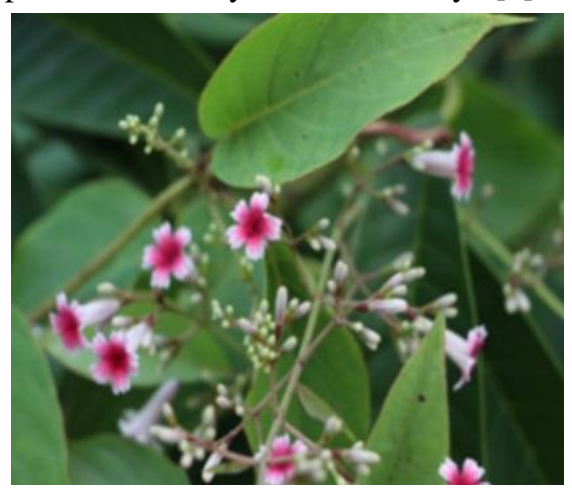

Gambar 1. Sembukan (Paederia foetida) [8]

Banyak penelitian ilmiah yang menunjukkan sembukan memiliki potensi besar di bidang kesehatan, seperti [9] dan [10], yang menyatakan bahwa tanaman sembukan berfungsi sebagai anti oksidan karena mengandung senyawa fenolik yang sangat tinggi. Namun, masih belum ada penelitian tentang analisis kandungan senyawa metabolit sekunder pada tanaman sembukan, khususnya pada dentang tanaman obat merupakan daun dan batang sembukan.

Berdasarkan latar belakang di atas, maka tujuan dari penelitian ini adalah melakukan skrining fitokimia daun dan batang sembukan dengan menggunakan dua pelarut yang berbeda, yaitu etanol 96\% dan metanol untuk mengetahui kandungan senyawa alkaloid, saponin, tanin dan flavonoid.

\section{METODE PENELITIAN}

Tanaman sembukan yang digunakan dalam penelitian ini diambil di Kabupaten Sumenep, Madura.

\subsection{Alat}

Adapun alat-alat yang digunakan dalam penelitian ini adalah blender, ayakan, toples untuk maserasi, corong, beker glas, labu ukur, pengaduk, tabung reaksi, pipet, spatula.

\subsection{Bahan}

Sedangkan bahan yang digunakan adalah daun dan batang sembukan, kertas saring Whatman No. 1, aluminium foil, kapas lemak, pereaksi Mayer, pereaksi Wagner, pereaksi Danderdroff, serbuk Mg, HCl 2N, larutan besi (III) klorida $10 \%$.

\subsection{CaraKerja}

\subsubsection{Pengambilan Sampel}

1 kg sampel tanaman sembukan dicuci bersih dengan air kran yang mengalir, kemudian dipilah antara daun dan batangnya. Kemudian dikeringanginkan. Setelah kering, masing-masing daun dan batang diblender dan diayak sehingga menjadi serbuk halus [11].

\subsubsection{Proses Ekstraksi}

Proses ekstraksi dilakukan dengan metode maserasi. Masing-masing 10 gram serbuk halus daun sembukan direndam ke dalam $100 \mathrm{ml}$ pelarut etanol 96\% dan $100 \mathrm{ml}$ pelarut metanol selama 5 hari sambil sesekali diaduk. Kemudian dilakukan penyaringan, dimaserasi kembali dengan jumlah pelarut dan hari yang sama, dan dimaserasi lagi sampai ampas tidak berwarna. Perlakuan yang sama untuk sampel batang sembukan.

\subsubsection{Skrining Fitokimia}

Lalu dilakukan skrining fitokimia untuk mengetahui adanya senyawa metabolit sekunder alkaloid, saponin, tanin dan flavonoid pada masingmasing ekstrak etanol $96 \%$ dan metanol daun dan batang sembukan. Identifikasi senyawa metabolit sekunder ekstrak daun dan batang sembukan menurut metode Harborne [11].

A. Alkaloid

Sampel ekstrak dilarutkan ke dalam $5 \mathrm{ml} \mathrm{HCl}$ $2 \mathrm{~N}$, dipanaskan selama 5 menit lalu disaring. Larutan yang diperoleh kemudian dibagi ke dalam 4 tabung reaksi. Tabung reaksi yang pertama ditambahkan dengan 3 tetes $\mathrm{HCl} 2 \mathrm{~N}$ yang berfungsi sebagai blanko. Tabung kedua, ketiga dan keempat masingmasing ditambahkan 3 tetes pereaksi Mayer, Wagner dan Danderdroff. Hasil positif bila terjadi endapan warna putih (Mayer), coklat (Wagner), dan jingga (Danderdroff).

\section{B. Saponin}

$2 \mathrm{ml}$ sampel dilarutkan ke dalam ke dalam aquades dan ditambahkan 10 tetes $\mathrm{KOH}$ pada tabung reaksi. Lalu dipanaskan ke dalam penangas air pada suhu $50{ }^{0} \mathrm{C}$ selama 5 menit. Dikocok selama 5 menit. Terbentuknya busa setinggi $1 \mathrm{~cm}$ dan tetap stabil selama 10 menit menunjukkan adanya senyawa saponin.

C. Tanin

$2 \mathrm{ml}$ sampel direaksikan dengan larutan besi (III) klorida $10 \%$, dan hasil positif menunjukkan 
adanya tanin bila terbentuk warna biru tua atau hijau kehitaman.

\section{Flavonoid}

$2 \mathrm{ml}$ sampel dilarutkan ke dalam $2 \mathrm{ml}$ metanol, dan ditambahkan dengan sedikit serbuk $\mathrm{Mg}$ dan 5 tetes $\mathrm{HCl} 2 \mathrm{~N}$. Terbentuknya warna merah atau jingga menunjukkan adanya senyawa flavonoid.

\section{HASIL DAN PEMBAHASAN}

Tujuan dari pencucian sampel dengan air kran yang mengalir untuk membersihkan segala kotoran (debris) yang menempel. Lalu dilakukan pengeringan untuk menghilangkan kadar air dalam sampel. Setelah kering, kemudian sampel daun dan batang diblender untuk memperoleh serbuk halus. Menurut [11], serbuk halus yang akan digunakan dalam proses ekstraksi dapat memperluas kontak antara pelarut dengan sampel, sehingga pelarut lebih mudah menarik senyawa yang terkandung dalam sampel tersebut. Selanjutnya, serbuk halus yang didapat dilakukan proses ekstraksi dengan metode maserasi.

Proses ekstraksi dilakukan dengan metode maserasi karena prosesnya mudah dan sederhana. Maserasi merupakan proses dimana sampel direndam ke dalam pelarut tertentu dan dapat diatur waktu lama perendamannya. Selama proses perendaman, dilakukan pengadukan secara kontinu. Tujuannya untuk mencegah memadatnya serbuk sampel dalam pelarut, karena bila terjadi pemadatan maka pelarut akan sulit untuk menembus dan menarik senyawasenyawa yang ada pada sampel tersebut. Pelarut yang digunakan untuk mengektrak daun dan batang sembukan adalah pelarut etanol $96 \%$ dan metanol. Etanol $96 \%$ dan metanol merupakan pelarut universal yang bersifat polar dapat melarutkan sebagian besar golongan senyawa [11]. Menurut [12], metanol dapat menarik alkaloid, steroid, saponin dan flavonoid.

Skrining fitokimia dilakukan untuk mengetahui kandungan senyawa yang terdapat dalam ekstrak tanaman [11]. Dalam skrining fitokimia, digunakan reagen kimia untuk mengetahui senyawa alkaloid, saponin, tanin dan alkaloid berdasarkan terbentuknya warna pada sampel setelah diberi reagen uji. Adapun hasil skrining fitokimia daun dan batang sembukan dapat dilihat pada Tabel 1 berikut.

\section{Tabel 1. Hasil skrining fitokimia ekstrak daun dan batang sembukan pada 2 pelarut yang berbeda}

\begin{tabular}{|c|c|c|c|c|c|c|c|c|}
\hline \multirow{2}{*}{ Sampel } & \multicolumn{4}{|c|}{ Ekstrak Etano1 $96 \%$} & \multicolumn{5}{c|}{ Ekstrak Metanol } \\
\cline { 2 - 9 } & Alkaloid & Saponin & Tanin & Flavonoid & Alkaloid & Saponin & Tanin & Flavonoid \\
\hline Daun & + & - & + & + & + & - & + & + \\
\hline Batang & + & + & + & + & + & + & + & 0 \\
\hline
\end{tabular}

Masing-masing ekstrak etanol dan metanol pada daun sembukan mengandung alkaloid, tanin dan flavonoid, tapi tidak mengandung saponin karena tidak terbentuknya busa saat pengujian fitokimia. Namun mengandung pada batang mengandung alkaloid, saponin, tanin dan flavonoid. Dari hasil tersebut, kemudian masing-masing senyawa metabolit sekunder yang telah teridentifikasi dianalisis aktivitas biologisnya.

Umumnya senyawa metabolit sekunder yang terdapat dalam tanaman yaitu alkaloid, flavonoid, steroid, saponin, terpenoid dan tanin [11]. Di bidang farmakologi, senyawa metabolit sekunder banyak dimanfaatkan sebagai bahan obat [13] seperti antioksidan, antibiotik, antikanker, antiserangga [14], agen antitumor, feromon, agen immunomodulasi, serta merangsang pertumbuhan hewan dan tumbuhan [15].

Senyawa metabolit sekunder alkaloid mengandung nitrogen dan bersifat basa. Alkaloid mempunyai efek farmakologis, diantaranya sebagai pemicu sistem saraf, anti bakteri dan anti jamur, mengobati penyakit jantung, menaikkan tekanan darah dan lain-lain $[16,17]$. Alkaloid ini rasanya pahit dan tidak berwarna. Fungsi lain dari alkaloid yaitu sebagai pelindung tanaman dari serangga dan herbivora [18].

Saponin berfungsi sebagai antibakteri, yang bekerja dengan menurunkan tegangan permukaan dinding sel bakteri sehingga permeabilitas membran sel bakteri menjadi rusak dan akhirnya terjadi kematian sel [19]. Saponin digunakan sebagai deterjen, pestisida dan antimoluska [20].

Tanin berfungsi sebagai antimikroba [21]. Aktivitas biologi lain dari tanin yaitu sebagai antioksidan, pencegah diare dan sebagai astringen [22].

Flavonoid adalah golongan senyawa fenol yang dihasilkan oleh tanaman. Fungsi dari flavonoid yaitu sebagai antioksidan alami [23] untuk menangkal radikal bebas [24] dan bersifat racun bagi organisme lain dimana flavonoid akan mengganggu fungsi dari protein sel sehingga pembelahan sel menjadi terganggu [25]. Selain itu, senyawa ini berfungsi 
untuk menarik serangga dan menyebarkan biji [18]. Aktivitas biologis flavonoid yang lainnya adalah sebagai anti untuk mencegah pembekuan darah, anti peradangan pada pembuluh darah, anti peradangan, antivirus, antitumor dan mencegah terjadinya pengeroposan tulang [26].

\section{KESIMPULAN}

Pada ekstrak etanol dan metanol daun sembukan mengandung alkaloid, tanin dan flavonoid. Sedangkan pada ekstrak etanol dan metanol batang sembukan mengandung alkaloid, saponin, tanin dan flavonoid. Senyawa metabolit sekunder alkaloid, saponin, tanin dan flavonoid memiliki potensi lain untuk dikembangkan sebagai bahan obat baru baik di bidang kesehatan maupun di bidang yang lainnya untuk kesejahteraan manusia.

\section{UCAPAN TERIMA KASIH}

Penulis mengucapkan terima kasih kepada Akademi Farmasi Surabaya dan semua pihak yang telah memberikan dukungan dan fasilitas sehingga penulis dapat menyelesaikan artikel ini.

\section{PENDANAAN}

Penelitian ini tidak didanai oleh sumber hibah manapun.

\section{KONFLIK KEPENTINGAN}

Seluruh penulis menyatakan tidak terdapat potensi konflik kepentingan dengan penelitian, kepenulisan (authorship), dan atau publikasi artikel ini.

\section{DAFTAR PUSTAKA}

1. Khusbu C, Anar P, Mayuree P, Carol M, Roshni S, Subodh A. Paederia foetida Linn. As a potential medicinal plant: A Review. 2010;3(12)31353137.

2. Mabberley DJ. The Plant-book: A Portable Dictionary of the Vascular Plants Utilizing Kubitzki's The Families and Genera of Vascular Plants (1990-). Conqruist's An Integrated System of Classification of Flowering Plants (1981), and Current Botanical Literature, Arranged Largely on the Principles of Editions 1-6 (1896/97-1931) of Willis's A Dictionary of the Flowering Plants and Ferns Edisi ke-2. UK: Cambridge University Press Cambridge; 1997.
3. Pereira CG, Meireles MAA. Supercritical fluid extraction of bioactive compounds: Fundamentals, applications and economic perspectives. Food Bioprocess Tech. 2010;3:340-372.

4. Mongrand S, Badoc A, Patouille B, Lacomblez C, Chavent M, Bessoule JJ. Chemotaxonomy of the Rubiaceae family based on leaf fatty acid composition. Phytochemistry. 2005;66:549-559.

5. Martins D, Nunez CV. Secondary Metabolites from Rubiaceae Species. Molecules. 2015;20:1342213495.

6. Nurcahyanti ADR, Wandra J. Kurang Sedap Namun Berkhasiat Hebat. BioS-Majalah Ilmiah Semi popular. 2012;5(2):44-47.

7. RSUA (Rumah Sakit Universitas Airlangga). Tanaman Kentutan Si Penawar Racun. 2013; diakses tanggal 15 Juli 2018.

8. Patel DK. Paederia Foetida Linn.: A Potential Climbing Medicinal Herb in Central India. International Journal of Environmental Sciences \& Natural Resources. 2017;6(5):01-07.

9. Osman H, Rahim AA, Norhafizah MI, Bakhir NM. Antioxidant activity and phenolic content of Paederia foetida and Syzygium aqueum. Molecules. 2009;14:970-978.

10. Nosalova GN, Mokry J, Ather A, Khan. Antitussive Activity of the Ethanolic Extract of Paederia foetida (Rubiaceae family) in NonAnaesthetized Cats. Acta Veterinaria Brno. 2007;76:27-33.

11. Harborne JB. Phytochemical methods: A Guide to Modern Techniques of Plant Analysis Edisi ke5. London: Chapman and Hall Ltd; 1998.

12. Thompson EB. Drug Bioscreening America. Graceway Publishing Company Inc. 1985.

13. Kumari P, Kumari C, Singh PS. Phytochemical Screening of Selected Medicinal Plants for Secondary Metabolites. Int.J.Life.Scie.Scienti.Res. 2017;3(4):11511157.

14. Saifudin A. Senyawa alam metabolit sekunder:Teori, konsep, dan teknik pemurnian. Yogyakarta;2014.

15. Nofiani R. Artikel ulas balik: Urgensi dan mekanisme biosintesis metabolit sekunder mikroba laut. Jurnal Natur Indonesia. 2008;10(2):120-125.

16. Lumbanraja LB. Skrining Fitokimia dan Uji Efek Antiinflamasi ekstrak etanol daun lempuyang (Sonchus arvenis L.) terhadap radang pada tikus. Medan: Universitas Sumatera Utara; 2009. 
17. Robinson T. Kandungan organik tumbuhan tinggi. Terjemahan: Koensoemardiyah. Semarang: IKIP Press; 1995.

18. Croteau R, Kutchan TM, Lewis NG. Natural products (secondary metabolites). Biochemistry \& Molecular Biology of Plants. 2000;24:12501318.

19. Madduluri S, Rao KB, Sitaram B. In vitro evaluation of antibacterial activity of five indigenous plants extracts against five bacteria pathogens of humans. International Journal of Pharmacy and Pharmaceutical Sciences. 2013;5(4):679-684

20. Shi J, Arunasalam D, Yeung D, Kakuda Y, Mittal G, Jiang Y. Saponins from edible legumes: Chemistry, processing and health benefits. J. Med. Food. 2004;7:67-78.

21. Sudira IW, Merdana I, Wibawa I. Uji daya hambat ekstrak daun kedondong (Lannea grandis Engl) terhadap pertumbuhan bakteri Erwinia carotovora. Buletin Veteriner Udayana. 2011;3(1):45-50.

22. Desmiaty Y, Ratih H, Dewi MA, Agustin R. Penentuan Jumlah Tanin Total pada Daun Jati Belanda (Guazuma ulmifolia Lamk.) dan Daun Sambang Darah (Excocaria bicolor Hassk.) Secara Kolorimetri dengan Pereaksi Biru Prusia. Ortocarpus. 2008;8:106-109.
23. Saija A, Scalese M, Lanza M, Marzullo D, Bonina F, Castelli F. Flavonoids as antioxidant agents: importance of their interaction with biomembranes. Free Radic. Biol \& Med. 1995;19(4):481-486.

24. Ningsih W. Evaluasi senyawa fenolik (asam ferulat dan asam p-Kumarat) pada biji, kecambah, dan tempe kacang tunggak (Vigna unguiculata) (skripsi). Bogor: Institut pertanian Bogor; 2007.

25. Sirikantaramas S, Yamazaki M, Saito. Mechanisms of resistance to self-produced toxic secondary metabolites in plants. Phytochem. Rev. 2008;7:467-477.

26. Simanjuntak K. Peran antioksidan flavonoid dalam meningkatkan kesehatan. Bina Widya. 2012;23(3):135-140.

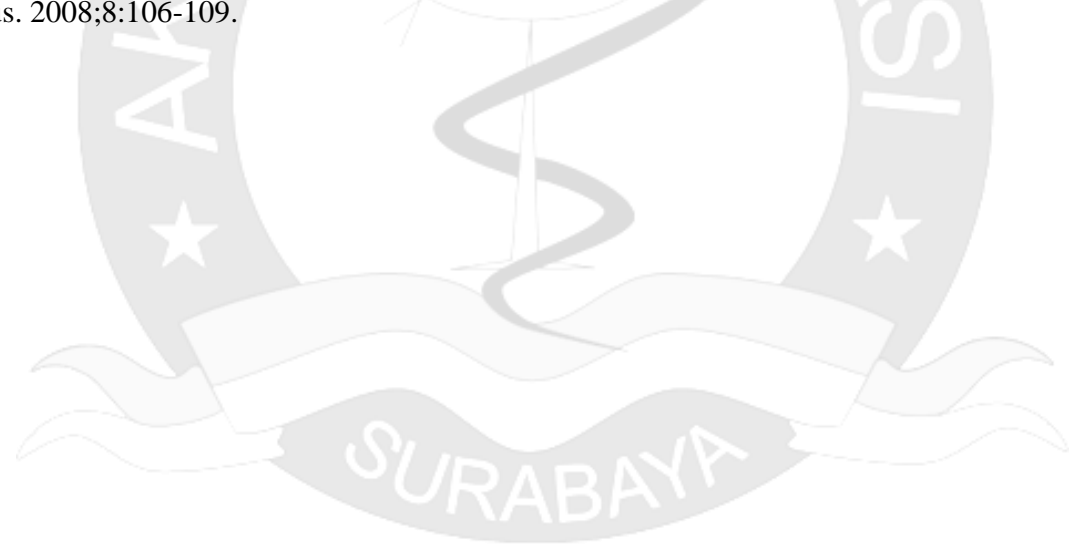

